\title{
Does Environment Management Practice Play a Mediating Role between Green Intellectual Capital and Green Human Resource Management?
}

\section{Mohammad Nurul Alam}

Universiti Tenaga Nasional

Jamshid Ali Turi ( $\sim$ jamshidump@gmail.com )

Bahria University Department of Management Sciences

\section{Sudhaishna Khastoori}

SZABIST: Shaheed Zulfikar Ali Bhutto Institute of Science and Technology

\section{Rosima Bte Alias}

Universiti Tenaga Nasional

\section{Md Adnan Rahman}

International University of Business Agriculture and Technology

\section{Md Suliman Hossin}

University of Kuala Lumpur: Universiti Kuala Lumpur

\section{Research Article}

Keywords: Environment Management Practice, Green Human capital, Green Relational capital, Green HRM, Green Intellectual Capital

Posted Date: May 24th, 2021

DOl: https://doi.org/10.21203/rs.3.rs-443303/v1

License: (9) This work is licensed under a Creative Commons Attribution 4.0 International License. Read Full License 


\section{Abstract}

The study aimed to examine the mediating role of environment management practices between green intellectual capital and green human resource management. A positivism philosophy, explanatory research design and quantitative research methodology was employed for collecting data from 125 ready-made garment manufacturing firms in Bangladesh. Smart-PLS 3.2.9 was used to observe the proposed relationship. The results indicated that environment management practice has a significant influence in the relationship between green human capital and green human resource management, and green relational capital and green human resource management. Surprisingly, environment management practice does not play any significant mediating role in between green structural capital and green human resource management. In addition, green human capital and green relational capital has a significant direct influence on green human resource management. However, green structural capital does not have any significant direct impact on green human resource management.

\section{Introduction}

The concept of being green has acquired huge consideration from both practitioners and scholars over the last several years (Su \& R.Swanson, 2019; Paço, Shiel, \& Alves, 2019). In academics, the research has progressively expanded from a prevailing consideration on "Green Business" to "Greening" the functional units within organizations that include green supply chain management (GSCM), Green Purchasing, Green Finance, Green Innovation, Green Information Technologies, green management, and green human resource management (Hickel \& Kallis, 2020; Paço, Shiel, \& Alves, 2019). Considering that businesses operate in an extremely competitive market, therefore, they should be both efficient to provide value as well as act in a responsible way. Accordingly, the penetrating environmental issues (across the world) has driven businesses to adopt several environmental practices, such as, conducting "green and competitive" activities (Jennings \& Bamkole, 2019; RenataDagiliūtè, Liobikienė, \& Minelgaitè, 2018). In order to achieve green agenda, researchers have proposed that "Human Resource Management" contribute viral part in implanting the green procedures within functions of HRM that could possibly strengthen the organization's sustainability (Colding, et al., 2020; B.Hodson \& A.Sander, 2017; Colding, et al., 2020). In a study, Derkzen, Teeffelen, \& Verburg (2017) have emphasised that former research has examines the relations between HRM and Intellectual Capital (IC). Nonetheless, former studies haven't discussed directly the relation between green HRM and green IC. In the same way, (Bongartza, et al., 2018) claimed that knowledge could be gained at different organizational level; thus, IC could be considered as a dynamic force to form and implement HRM practices within a firm. Furthermore, Groening, Sarkis, \& Zhu (2018) and Alam, Azim, \& Alias (2017) and Alam, Alias, \& Hassan (2019) also discussed that no study had examined IC with reference to "ecological management" or "green innovation". In a research, Meijerink \& Bondarouk (2018) explored that businesses investing lots of resources and huge efforts in green IC cannot only fulfil the rigid international ecological principles and widely known awareness of consumers regarding environment, but ultimately attain a corporate competitive edge as well. This is well appropriate for business in the developing countries to attract the best fit talents, obtain competitive edge 
and still uphold sustainable environment. As a result, this is a valuable opportunity for research to be conducted in future. The afore-mentioned bases indicates conducting a research to analyse the relationships between green IC practices with green HRM.

Shukla (2020) and Sokolov \& Zavyalova (2020) propose that management of IC and strategic development helps the senior directors to maximize the intellectual resources of organization. Moreover, Groening, Sarkis, \& Zhu, (2018) contributed that IC could provide senior directors with a higher stock of knowledge and encourage educated strategic decisions in HRM for future potential organizational challenges.

IC may provide senior executives with a greater pool of knowledge to make more informed strategic HRM decisions for future organizational challenges. In the 21st century, one of the new challenges that firms are experiencing is how the HRM practices of organization can turn out to be green (Mansoor, Jahan, \& Riaz, 2021) (Hickel \& Kallis, 2020). Considering the existing literature and these suggestions, it is important to study the relationships between green HRM and green IC. Accordingly, the research question of this study to be answered is: Does green IC (i.e. green structural capital, green human capital, and green relational capital etc.) foresee the green HRM?

In view of above information, these three components of green IC (green structural capital, green human capital, and green relational capital) will be determine to examine the impact of these components on green HRM. In order to attain this objective, a survey was carried out among 112 large manufacturing organizations operating in Malaysia and Bangladesh. This would give a high global understanding to the extant literature, in the same connection arises from western nations.

For a developing nation like Malaysia and Bangladesh, the demand for extremely competent employees together with emphasis on sustainable environmental practices is vital (Fukuda \& Tanaka, 2020; Chiappini \& Lahet, 2020). Moreover, in the recent years the economies of emerging nations have become highly important due to increasing need of their human resources (contribute vital role to enhance their GDP). Many scholars have arrived a consensus that developing markets are the foremost destination for the firms from different industries globally (Yuslizaa, et al., 2020; Groening, Sarkis, \& Zhu, 2018). This is due to adequate resources and large pool of talents available in these regions. Therefore, it is essential to understand more regarding green HRM in developing nations. The related literature would be provided in the following section. Afterwards, hypotheses of research would be presented, followed by the description of the methodology. Subsequently, the results of this empirical research would be examined and discussed. In the end, both theoretic as well as applied consequences would be provided.

\section{Literature Review \\ 2.1. Green HRM}

The 21st century is best described as the century of culturally diverse markets widely growing geographically all across the world (Mousa \& Othman, 2020). Green HRM has turn out to be vital today 
due to many reasons, such as, many negative environmental case have been presented (Saeed, et al., 2018; Mousa \& Othman, 2020). In addition, firms use natural resources in order to manufacture products that mainly results in pollution and wastage, harming the surrounding environment. Moreover, environmental imbalances, pollution, and global warming are observed as by-products of additional use of natural resources that are used as basic materials (Tang, Chen, Jiang, Paillé, \& Jia, 2018; Pham, Tučková, \& Jabbour, 2019). In developing nations, such as, Bangladesh and Malaysia, the concern for green practices has widely become prominent. One reason is that developing countries have started using natural resources and more energy in recent years and, consequently contributed a lot to ecological degradation (Yusoff, Nejati, Kee, \& Amran, 2020; Hickel \& Kallis, 2020). For instance, Malaysia had average growth rates of Carbon Dioxide emissions slightly higher than $6 \%$ annually, approximately behind that of Peoples' Republic of China with $7.42 \%$ (second largest country across the globe), (Singh, DelGiudice, Chierici, \& Graziano, 2020; Yong, et al., 2020). Former scholars have argued that the process in which green HRM practices can be promoted is studied often with reference to continuum containing all the HRM events i.e. job analysis and descriptions, selection and recruitment, performance appraisal, training and development, and compensations (B.Hodson \& A.Sander, 2017; Kianto, Sáenz, \& Aramburu, 2017). In accordance with Pham, Thanh, Tučková, \& NgocThuy (2020), the recent researhces discussess green HR methods and individual human behaviors, together with new theoritical guidelines and multilevel dynamics. Moreover, the paper also asissted increasing green HRM scholarship in different ways, which include analysing green HR practices, impact of green HRM on individual and organizational performance, and wider contextual problems (Derkzen, Teeffelen, \& Verburg, 2017; Jennings \& Bamkole, 2019). Scholars have proposed that HRM can highly contribute in enabling transformation to green HRM through selecting employees on the basis of truthful criteria, by providing training and development to enhance employees KSA's in ecological management, and by introducing proper performance evaluation and rewards system (Yu, Chavez, Feng, Wong, \& Fynes, 2020; Singh, DelGiudice, Chierici, \& Graziano, 2020). Saeed, et al., (2018) found that green practices in HRM start at the minute of employee's recruitment and continue until his last day in the organization. However, the sustainble supervision of 3P's i.e. people, product and process in developing markets isn't a simple job, and firms should always develop a sustainable plan to take maximum advantage of "marker-share" and mind-share" philosophy (Yu, Chavez, Feng, Wong, \& Fynes, 2020). The generic practices in HRM have been combined with green elements; thus, the word "green" has been included in HRM practices to avoid the misunderstanding (Anwar, et al., 2020; Agyabeng-Mensah, et al., 2020).

Green HRM plays vital role in supporting other functions to maintain organization's competitive advantage in different ways (Derkzen, Teeffelen, \& Verburg, 2017; Jennings \& Bamkole, 2019). B.Hodson \& A.Sander (2017), concluded that direct impact of ecological performance on the competitive edge was higher for organizations with lesser HR practices. Moreover, their finding also demonstrated that the organizations with reputable HR practices obtain highly balanced competitive edge through significant combination between better ecological and organizational performance (Colding, et al., 2020; Mousa \& Othman, 2020). Bongartza, et al. (2018), suggested a synergistic integrated model to enhance the contribution of Green SCM and green HRM in transforming organizations to become more sustainable. In 
the same manner, Saeed, et al. (2018) and Bongartza, et al. (2018), concluded that green trainnnig prefers helping organizations in enhancing green SCM, reducing costs, sustainable organizational practices, attract huge talent for the recruitment. Anwar, et al. (2020) proposed that green practices in HR tends to support the firms in endorsing the ecological elements of their sustainable development measures. Furthermore, Islam, Jantan, Aldaihani, Rahman, Shahin, \& Alam (2018), discovered the paradoxes related to HRM in enhancing the ecological sustainability. Moreover, Sokolov \& Zavyalova (2020), emphasised on the significance of green HRM system in order to change the concept of "sustainable-centre" in sports facilities across Malaysia and globally. These researches showed that green practices in HRM resulted in sustainability, specifically from the perspective of environment. Nonetheless, few researches has studied the relation between green HRM and green IC; therefore, evidence of such relations seems to be indecisive.

\subsection{Green Intellectual Capital}

Researches on intellectual capital have gain huge attention of scholars, and the significance of IC has been emphasized on in the management literature (Yusoff, Omar, Delim, Zaman, \& Samad, 2019). Nevertheless, IC comprising ecological concepts i.e. green IC was introduced only by Chen in year 2008 and hasn't emerged as a crucial area of study until in recent times (Massaro, Dumay, Garlatti, \& Mas, 2018). The definitions of environmental IC and green IC are rare in management literature. In particular, Derkzen, Teeffelen, \& Verburg (2017) described green intellectual capital as "the entire stock of all the types of intangible assets, capabilities, relationships, and knowledge, etc. regarding green innovation or environmental safety at individual and organizational level within an organization". Likewise, Yong J. Y., Yusliza, Ramayah, \& Fawehinmi (2019) described green intellectual as "the combination of green and environment familiarity sources and understanding capacity of organizations to enhance the competitive edge". Moreover, Villiers \& Sharmac (2020) suggested green intellectual capital as "the stock of overall knowledge that a company is capable to take advantage in the process of undertaking environmental management in order to gain the competitive edge". Intangible resources can be considered to be scare and easily not imitated. The belief is that competencies and intangible assets highly contribute in obtaining and sustaining the higher performance than do tangible assets(Mousa \& Othman, 2020) and plays vital role for organizations survival in ever-changing market environments. In addition, green intellectual capital facilitate companies to fulfil demanding international environmental rules, to comply with growing ecological awareness increasing among consumer's, and to add value in the organizational processes (Cavicchi, 2017; Sokolov \& Zavyalova, 2020). The literature has found three dimensions that generally integrate the category of green Intellectual Capital, 1) Green Human Capital; 2) Green Structural / Organizational Capital; and 3) Green Relational Capital.

Green Human Capital is the "sum of employees, skills, knowledge, experience, wisdom, capabilities, attitude, commitments, and creativities, etc. regarding protection of environment or green creativity", and has been implanted in employees not in the companies' (Delgado-Verde, Amores-Salvadó, Castro, \& Navas-López, 2014). Moreover, human capital is considered as an essential aspect of IC process that contributes the role of driving force for Green Structural Capital and Green Relational Capital (Cavicchi, 
Caterina; Vagnoni, Emidia, 2017). These aspects neither owned by firms nor be imitated. The characteristics of employee's that could incorporate explicit or tacit knowledge are very crucial assets in achieving prosperous green HRM (Derkzen, Teeffelen, \& Verburg, 2017). For this reason, these characteristics are a form a competitive edge for a firm. GHC is considered as a vital strategic resource for sustainable competitive edge in today's age of ever-changing environment (Mas, 2019). Human Capital is very important element of Intellectual Capital. The opinion is that companies that encourage the relevance of human capital by investing in their people attain the better organizational performance (Derkzen, Teeffelen, \& Verburg, 2017; Saeed, et al., 2018). Human Capital run in parallel with other resources of organization and capabilities, i.e. green HRM (Hassan, Jambulingam, Alam, \& Islam (2019); Alam, Hassan, Bowyer, \& Reaz, 2020).

Green Structural Capital refers to the "sum of organizational knowledge management systems, capabilities, commitments, information technology, rewards system, operation processes, databases, organizational culture, managerial mechanism and philosophies, company's reputation, trademarks, copy rights, and patents, etc. regarding green innovation within organization or environmental safety" (Xu \& Wang, 2018; Pham, Tučková, \& Jabbour, 2019). Further, GSC in other words is the "institutionalised knowledge regarding the form of organizational structures, processes, policies, technologies and culture". These assets are important intangible resources belonged to organization and can be used to strengthen the organizational green HRM (Jennings \& Bamkole, 2019; Mousa \& Othman, 2020). However, an environmental culture of an organization can refers to the set of values, organizational culture, assumptions, and symbols (Rehman, Kraus, Shah, Khanin, \& Mahto, 2017), and consistent with Meijerink \& Bondarouk (2018), an important relation exists between green HRM and organizational culture. Moreover, e-HRM that is vital part of IT system of Green Structural Capital, was found to have a relation with green practices of HRM (Alfaro-Navarro, López-Ruiz, \& Peña, 2017; Akhtar, Ismail, Ndaliman, Hussain, \& Haider, 2015; Abhayawansa, Guthrie, \& Bernardi, 2019).

Green Relational Capital refers to the "sum of an organizations collaborative relations with customers, network members, suppliers, and other partners regarding green innovation and corporate environmentfriendly management that makes it possible to create fortunes and obtain a competitive edge" (Mansoor, Jahan, \& Riaz, 2021; Pham, Tučková, \& Jabbour, 2019). Delgado-Verde, Amores-Salvadó, Castro, \& NavasLópez, (2014) desctibe GRC an an intangible resource that emphasises on developing, nurturing and maintaining great relationships with any company, groups or individuals that may influence the standing on a company within market (Paço, Shiel, \& Alves, 2019). Therefore, it is important for the companies to line up their interest with those of their stakeholders in order to survive and remain ahead in the line of competition. Nonetheless, adopting "Green Practices" is a widespread interest for primary stakeholders, i.e. customers, government, and suppliers. Thus, there is increasing pressure on companies to adopt green HRM practices. For example, indicated that customer pressure has a huge connection with the green HRM (B.Hodson \& A.Sander, 2017; Massaro, Dumay, Garlatti, \& Mas, 2018; Pham, Thanh, Tučková, \& NgocThuy, 2020).

\subsection{Hypothesis Development}


The theoretical background of this research constitute its basis on Capital Based View Model (ICV). A few but influential scholars, including Sveiby (1997) and Edvinson and Malone, (1997) figured out the ICV as covered in (Yong J. Y., Yusliza, Ramayah, \& Fawehinmi, 2019; Petty \& Guthrie, 2020). Moreover, this concept developed when other scholars exploit it, i.e. Reed, Lubatkin, \& Srinivasan (2006), ICV supports the Leonard- Barton's (1992), also widely known as knowledge based view (KBV) as covered by (Petty \& Guthrie, 2020; Petty \& Guthrie, 2020; Kianto, Sáenz, \& Aramburu, 2017). Even though the aim of both theories is to clarify the dynamics based on knowledge that inspire the value of an organization, and both are originated from Resource Based Theory (RBV), but evidently the focus of both theories is different. KBV mainly focuses on evaluating the effectiveness of a firm's use of Knowledge Management Tools as knowledge producing methods, for instance, its information management and information technology procedures (Nikolaou, 2019; Curado \& Bontis, 2006). Conversely, the ICV mainly throw focus on dynamics and concentration of Knowledge Capital embedded in an organization and is assumed to have a direct relation with the competitive advantage and organizational performance (Sousa \& Hendriks, 2006; Heiman \& Nickerson, 2010), it intended to specify its discussion on intangible assets. Moreover, based on RBV theory, an organization's intangible assets have higher degree of contribution in achieving and sustaining the higher organizational performance, when they are integrated or combined (Groening, Sarkis, \& Zhu, 2018). Nonetheless, the substantial criticism of resource based theory is that it is too general and do not contain clear description of competitive advantage (Martin \& Javalgib, 2019; Hörisch, Johnson, \& Schaltegger, 2015).

At the present time, when organizations cannot ignore the ecological issues, it is best time to examine the significance of green intellectual capital in the context of ecological management. In a research of CruzGonzález, López-Sáez, Navas-López, \& Delgado-Verde (2014), the findings showed that there is indirect impact of green organizational/structural capital on ecological product innovation by green social capital. These results emphasized that "green organizational capital" (for instance, environmental communication structures', responsibilities, procedures and policy) had no positive and direct relationship with the environmental product innovation. Considerably, the effectiveness of environmental product innovation heavily dependent on the cooperation among employees i.e. green social capital.

Cruz-González J., López-Sáez, Navas-López, \& Delgado-Verde, (2015) and Groening, Sarkis, \& Zhu (2018), confired the direct impact of green human capital on green innovation performance, along with the mediation impact of green human capital on the direct positive relations between environmental corporate ethics and the two consquents; green innovation performance and green correspondance learning. They propose that organizations have to enhance their GHC to improve the extent of positive effects between two envionmental corportate ethics and two consquents. In HRM field, former researches have mostly emphasised the effect on practices of HR in various emerging aspects of intellectual capital (Alam \& Alias, 2018; Cavicchi, 2017). Nevertheless, (Wu, 2013) and Alam, Alias, \& Azim (2018), presented an opposing belief, they stated that strategic HRM, IC, and HRM theories are connected closely, and that IC must be the mainspring in these relations. Afterwards, they proposed that future study was needed to have greater knowledge of how individual components of IC effected the practices of HRM. According to meaningful relation found between green innovation and green IC, and to address gap that Kong and 
Thomson (2009) underlined and obtain a clear picture from the perspective of environment, this research suggests the following:

H1. Green human capital has positive relationship with green HRM.

H2. Green structural capital has positive relationship with green HRM.

H3. Green relational capital has positive relationship with green HRM.

These aforementioned three hypotheses (H1-3) are projected to examine the relationship between antecedent constructs (for instance, green structural capital, green human capital, and green relational capital), and the resultant constructs (i.e. green HRM) of ecological management practices. Following these hypothesis, the pyramid effect model could be employed in which environment management practices denote the organizations internal system (i.e. the cognitive element) as the result of organizations assessment of green structural, relational, and human capital and leads and resulting in their affective returns (i.e. green HRM). In other terms, structural, relational, and human capital provided by the organizations is unlikely to effect the affection until the firms' positive insight of ecological management practices arises. As a result, there is a possible case to examine the practices of environment management, as a mediating force between green structural capital, green human capital, green HRM, and green relational capital. Due to these reasons, the hypotheses are presented as follows:

H4: Environment management practices mediates the positive relationship between (a) Green Human Capital, (b) Green Structural Capital, and (c) Green Relational Capital.

\subsection{Conceptual Framework}

According to discussion presented through above literature, following conceptual framework has been developed, Fig. 1.

\section{Methodology}

This study designed to observe the mediating role of environment management practice (EMP) in between green intellectual capital and green HRM. To test these relationships, an email questionnaire was employed for collecting the data from 500 ready-made garment industry of Bangladesh. The survey instrument was adopted and adapted from Yong, Yusliza, Ramayah \& Fawehinmi (2019), Jabbour (2011) and Yong and Yusoff (2016), and Chen (2008). A 5-point Likert-type scale was employed. In questionnaire, 10 items were used to measure green HRM, 8 items were used to measure EMP, 5 items were employed to measure green human capital, 9 items were employed to measure green structural capital and 5 items were used to measure green relational capital. The sampling frame was all the readymade garment factories in Tongi area. The sampling frame was obtained from the Bangladesh Garment Manufacturers \& Exporters Association (BGMEA) Directory 2020. Using the BGMEA Directory 2020, a total of 500 RMG companies were identified as largest based on the employee sizes and all these firms were included for the study. As such, the all 500 RMG firms were emailed a survey. The questionnaires were 
addressed to the HR managers or HR directors who were currently working in HRM. As a result 500 questionnaires were distributed with a cover letter that ensured the anonymity of answers and that encompassed a brief description of the study. However, 125 filled questionnaires were return from the respondents. Therefore, the collected data set was 125 that proceed for analysis.

\section{Data Analysis And Findings}

For analysing the collected data for this study, the Smart-PLS 3.2.9 and SPSS 23 software were used (Ringle, Wende \& Becker, 2015). Firstly, the demographic variables were analysed using descriptive studies of SPSS. Secondly, two step techniques was used for assessing the proposed relationships, first step was the measurement model for checking construct validity, reliability, and convergent validity and in second step the structural model was developed for testing the hypothesis (Anderson \& Gerbing, 1988; Hair, Hult, Ringle, \& Sarstedt, 2017). Table 1 is representing the demographic information about the respondents and the companies below.

Table 1

Demographic information about respondents and companies

\begin{tabular}{|lll|}
\hline Position & Frequency (n) & Percent (\%) \\
\hline Manager (HR) & 27 & 21.43 \\
\hline DGM (HR) & 39 & 30.95 \\
\hline GM (HR) & 41 & 32.54 \\
\hline Director (HR) & 18 & 14.29 \\
\hline Company Type & Frequency (n) & Percent (\%) \\
\hline Woven & 38 & 30.16 \\
\hline Knit & 46 & 36.51 \\
\hline Sweater & 41 & 32.54 \\
\hline No. of Employees & Frequency (n) & Percent (\%) \\
\hline less than 1000 & 17 & 13.49 \\
\hline 1000 to 3000 & 42 & 33.33 \\
\hline 3001 to 5000 & 37 & 29.37 \\
\hline above 5000 & 29 & 23.02 \\
\hline
\end{tabular}

Table 1 explains the demographics of the respondents from where data was collected. The data was collected from the management cadre including Human Resource (HR) Manager, Deputy General Management (DGM-HR), General Manager (GM-HR) and Director (HR). Three (3) major industries of the 
country were selected for data collection, as they are having major role in the environmental effects.

Similarly, the employees were having better experiences as indicated by the last portion of the Table. No 1 , having better exposure to the management and their relation to environment related practices.

\subsection{Assessment of the Measurement Model}

To assess the measurement model, we examined the internal consistency reliability, convergent validity (see Table 2), and discriminant validity (see Table 3 and Table 4). To evaluate the internal consistency of the measures used, Cronbach's Alpha (CA) and composite reliability (CR) were employed, which ranged from (0.760 to 0.928$),(0.840$ to 0.940$)$ respectively, thus surpassing the 0.70 cut off in all the cases (Hair et al., 2017). For convergent validity, the factor loadings (FL) of all the items and the average variance extracted (AVE) was conducted. Convergent validity was confirmed because all the items' loading were more than 0.5 and the AVE for all the constructs were more than 0.5 thresholds (Holand, 1996; Hair et al., 2017). All the mentioned results are presented in Table 2, and Fig. 2. 
Table 2

Construct Validity and Reliability

\begin{tabular}{|c|c|c|c|c|}
\hline Constructs / Items & & $\mathrm{CA}$ & CR & AVE \\
\hline EMP & & 0.913 & 0.929 & 0.621 \\
\hline EMP1 & 0.775 & & & \\
\hline EMP2 & 0.811 & & & \\
\hline EMP3 & 0.796 & & & \\
\hline EMP4 & 0.739 & & & \\
\hline EMP5 & 0.823 & & & \\
\hline EMP6 & 0.774 & & & \\
\hline EMP7 & 0.800 & & & \\
\hline EMP8 & 0.786 & & & \\
\hline G. Human Capital & & 0.760 & 0.840 & 0.515 \\
\hline $\mathrm{GHC} 1$ & 0.789 & & & \\
\hline $\mathrm{GHC} 2$ & 0.731 & & & \\
\hline GHC3 & 0.560 & & & \\
\hline GHC4 & 0.779 & & & \\
\hline GHC5 & 0.706 & & & \\
\hline Green HRM & & 0.928 & 0.940 & 0.611 \\
\hline GHRM1 & 0.756 & & & \\
\hline GHRM10 & 0.668 & & & \\
\hline GHRM2 & 0.809 & & & \\
\hline GHRM3 & 0.856 & & & \\
\hline GHRM4 & 0.828 & & & \\
\hline GHRM5 & 0.788 & & & \\
\hline GHRM6 & 0.745 & & & \\
\hline GHRM7 & 0.818 & & & \\
\hline GHRM8 & 0.791 & & & \\
\hline
\end{tabular}

$\mathrm{FL}=$ Factor Loadings; $\mathrm{CA}=$ Cronbach's Alpha; $\mathrm{CR}=$ Composite Reliability, $\mathrm{AVE}=$ Average Variance Extracted. 


\begin{tabular}{|c|c|c|c|c|}
\hline Constructs / Items & & CA & CR & AVE \\
\hline GHRM9 & 0.738 & & & \\
\hline G.Relational Capital & & 0.792 & 0.856 & 0.543 \\
\hline GRC1 & 0.733 & & & \\
\hline GRC2 & 0.734 & & & \\
\hline GRC3 & 0.759 & & & \\
\hline GRC4 & 0.736 & & & \\
\hline GRC5 & 0.723 & & & \\
\hline G. Structural Capital & & 0.921 & 0.934 & 0.612 \\
\hline GSC1 & 0.774 & & & \\
\hline GSC2 & 0.754 & & & \\
\hline GSC3 & 0.826 & & & \\
\hline GSC4 & 0.719 & & & \\
\hline GSC5 & 0.731 & & & \\
\hline GSC6 & 0.772 & & & \\
\hline GSC7 & 0.829 & & & \\
\hline GSC8 & 0.831 & & & \\
\hline GSC9 & 0.796 & & & \\
\hline
\end{tabular}

\subsection{Discriminant Validity:}

There are various approaches to determine discriminant validity such as Fornell Lacker and Hetro TraitMono Trait (HTMT). Fornell Lacker is the first criterion that needs to confirm for discriminant validity. According to this process, the value of the square root of AVE of one construct must be higher than the value of inter-correlations between the constructs. As depicted in Table 3, the square roots of the AVE of all constructs are bigger than their corresponding inter-correlations values that confirm the discriminant validity through Fornell Larcker (Henseler et al. 2015). 
Table 3

Discriminant Validity (Fornell Larcker)

\begin{tabular}{|llllll|}
\hline Constructs & EMP & $\begin{array}{l}\text { G.Human } \\
\text { Capital }\end{array}$ & $\begin{array}{l}\text { G.Relational } \\
\text { Capital }\end{array}$ & $\begin{array}{l}\text { G.Structural } \\
\text { Capital }\end{array}$ & $\begin{array}{l}\text { Green } \\
\text { HRM }\end{array}$ \\
\hline EMP & 0.788 & & & & \\
\hline G.Human Capital & 0.240 & 0.718 & & & \\
\hline G.Relational Capital & 0.369 & 0.197 & 0.737 & & \\
\hline G.Structural Capital & 0.296 & 0.149 & 0.718 & 0.782 & 0.781 \\
\hline Green HRM & 0.450 & 0.396 & 0.438 & 0.375 & \\
\hline
\end{tabular}

With regards to discriminant validity, Henseler et al. (2015) proposed the Heterotrait-Monotrait Ratio (HTMT) method which confirms discriminant validity between each pair of variables. Table 4 shows that the HTMT values are below the threshold of 0.90 (Henseler et al. 2015).

Table 4

Discriminant Validity (HTMT)

\begin{tabular}{|llllll|}
\hline Constructs & EMP & $\begin{array}{l}\text { G.Human } \\
\text { Capital }\end{array}$ & $\begin{array}{l}\text { G.Relational } \\
\text { Capital }\end{array}$ & $\begin{array}{l}\text { G.Structural } \\
\text { Capital }\end{array}$ & $\begin{array}{l}\text { Green } \\
\text { HRM }\end{array}$ \\
\hline EMP & & & & & \\
\hline G.Human Capital & 0.284 & & & & \\
\hline G.Relational Capital & 0.414 & 0.249 & & & \\
\hline G.Structural Capital & 0.307 & 0.177 & 0.843 & & \\
\hline Green HRM & 0.476 & 0.467 & 0.509 & 0.401 \\
\hline
\end{tabular}

\subsection{Assessment of the Structural Model}

Hair et al. (2017) proposed six criteria for assessing the Structural Model using PLS-SEM. In the initial stage of assessing structural model, it is important to address the latent collinearity issues. Also, it is important to assess the significance and relevance of the structural model relationship, by assessing the level of variance explained of the dependent variable $\left(R^{2}\right)$, the level of effect size $\left(f^{2}\right)$, and the predictive relevance $\left(\mathrm{Q}^{2}\right)$. Moreover, it is also important to assess the corresponding t-values of the path coefficients via bootstrapping with 5,000 resamples. The assessment of the effect sizes of the relationships is important; as mentioned by Sullivan \& Feinn (2012), the p-value tells us whether the effect exists, but do not disclose the size of the effect. Therefore, all the results of R-square, F-square, Collinearity (inner VIF), and Predictive Relevance (Q-square) results presented in Table 5 hereunder. 
Table 5

Assessment of Structural Model

\begin{tabular}{|c|c|c|c|c|}
\hline \multirow[t]{3}{*}{ R-Square } & $\begin{array}{l}\text { Endogenous } \\
\text { Variables }\end{array}$ & R Square & $\begin{array}{l}\text { R Square } \\
\text { Adjusted }\end{array}$ & \multirow{3}{*}{$\begin{array}{l}\text { 0.26: Substantial, } \\
\text { 0.13: Moderate, } \\
\text { 0.02: Weak } \\
\text { (Hair et al., 2017) }\end{array}$} \\
\hline & EMP & 0.167 & 0.155 & \\
\hline & Green HRM & 0.363 & 0.350 & \\
\hline \multirow{5}{*}{$\begin{array}{l}\text { Effect Size } \\
\text { (F-Square) }\end{array}$} & $\begin{array}{l}\text { Exogenous } \\
\text { Variables }\end{array}$ & EMP & $\begin{array}{l}\text { Green } \\
\text { HRM }\end{array}$ & \multirow{5}{*}{$\begin{array}{l}\text { 0.26: Substantial, } \\
\text { 0.13: Medium effect, } \\
\text { 0.02: Small effect } \\
\text { (Hair et al., 2017) }\end{array}$} \\
\hline & EMP & & 0.100 & \\
\hline & $\begin{array}{l}\text { G.Human } \\
\text { Capital }\end{array}$ & 0.035 & 0.109 & \\
\hline & $\begin{array}{l}\text { G.Relational } \\
\text { Capital }\end{array}$ & 0.049 & 0.031 & \\
\hline & $\begin{array}{l}\text { G.Structural } \\
\text { Capital }\end{array}$ & 0.002 & 0.008 & \\
\hline \multirow{5}{*}{$\begin{array}{l}\text { Collinearity } \\
\text { (Inner VIF) }\end{array}$} & $\begin{array}{l}\text { Exogenous } \\
\text { Variables }\end{array}$ & EMP & $\begin{array}{l}\text { Green } \\
\text { HRM }\end{array}$ & \multirow{5}{*}{$\begin{array}{l}\text { VIF }<=5.0 \\
\text { (Hair et al., 2017) }\end{array}$} \\
\hline & EMP & & 1.201 & \\
\hline & $\begin{array}{l}\text { G.Human } \\
\text { Capital }\end{array}$ & 1.041 & 1.077 & \\
\hline & $\begin{array}{l}\text { G.Relational } \\
\text { Capital }\end{array}$ & 2.097 & 2.200 & \\
\hline & $\begin{array}{l}\text { G.Structural } \\
\text { Capital }\end{array}$ & 2.062 & 2.066 & \\
\hline \multirow{4}{*}{$\begin{array}{l}\text { Predictive } \\
\text { Relevance } \\
\text { (Q-Square) }\end{array}$} & \multirow{2}{*}{$\begin{array}{l}\text { Endogenous } \\
\text { Variables }\end{array}$} & CCR & $\mathrm{CCC}$ & \multirow{4}{*}{$\begin{array}{l}\text { Value larger than o indicates Predictive } \\
\text { Relevance (Hair et al., 2017) }\end{array}$} \\
\hline & & $\begin{array}{l}\mathrm{Q}^{2}(=1- \\
\text { SSE/SSO })\end{array}$ & $\begin{array}{l}\mathrm{Q}^{2}(=1- \\
\text { SSE/SSO) }\end{array}$ & \\
\hline & EMP & 0.099 & 0.516 & \\
\hline & Green HRM & 0.212 & 0.525 & \\
\hline
\end{tabular}

CCR: Constructs Cross-Validated Redundancy; CCC: Constructs Cross-Validated Communalities

Tables 6 present the findings related to our direct hypotheses, in support of first prediction, GRC was found significantly and positively related to Green HRM $(\beta=0.208, t=2.161, p<0.031$, Table 6$)$, and in terms of effect size $\left(f^{2}\right)$, the positive effect of GRC on the Green HRM can be considered to be small (Cohen, 1988). Similarity with regarding second prediction GSC was found no significant relationship ( $\beta=$ $0.103, t=1.186, p<0.236$, Table 6$)$. For the third prediction $(H 3)$, the statistical analysis revealed that 
there is a significant positive relationship between GHC and Green HRM $(\beta=0.274, t=3.754, p<0.000)$, and regarding the effect size $\left(f^{2}\right)$, can be considered to be small (Cohen, 1988). In the case of fourth hypothesis $(\mathrm{H} 4)$, the statistical analysis revealed that there is a significant positive relationship between EMP and Green HRM $(\beta=0.277, t=3.589, p<0.000)$, and the effect size $\left(f^{2}=0.100\right)$ showed small effect (Cohen, 1988). Hence, the $\mathrm{H} 1, \mathrm{H} 3$ and $\mathrm{H} 4$ were supported however the $\mathrm{H} 2$ was not supported. All the mentioned results presented in (Table 6 and Fig. 3).

Table 6

Path coefficient (direct effect) result

\begin{tabular}{|llllll|}
\hline Hypotheses & OS/Beta & SM & T & P Values & Decision \\
\hline H1: GRC $->$ Green HRM & 0.208 & 0.193 & 2.161 & 0.031 & Significant \\
\hline H2: GSC $->$ Green HRM & 0.103 & 0.114 & 1.186 & 0.236 & Not Significant \\
\hline H3: GHC $>$ Green HRM & 0.274 & 0.274 & 3.754 & 0.000 & Significant \\
\hline H4: EMP $>$ Green HRM & 0.277 & 0.279 & 3.589 & 0.000 & Significant \\
\hline OS: Original Means; SM: Sample Means & & & \\
\hline
\end{tabular}

Furthermore, the mediating effect of EMP in between GRC and Green HRM was found significant as the value $(\beta=0.081, t=1.975, p<0.049, L L=0.012, U L=0.168)$ as the $p$-value is lower than 0.05 and the results of $L L$ and $U L$ both are positive that means zero $(0)$ not in between that confirms mediation effect (Preacher and Hayes, 2008). Similarly, the mediating effect of EMP in between GHC and Green HRM was found statistically significant as the value $(\beta=0.048, t=2.102, p<0.036, L L=0.014, U L=0.100)$ as the $p$ value is lower than 0.05 and the results of $L L$ and $U L$ both are positive that means zero ( 0 ) not in between that confirms mediation effect (Preacher and Hayes, 2008). However, the mediating effect of EMP in between GSC and Green HRM didn't showed significant relationship as the value $(\beta=0.017, t=0.469, p<$ $0.639, L L=-0.057, U L=0.086$ ) as the $p$-value is higher than 0.05 and the value of $L L$ is negative and $U L$ is positive that means zero $(0)$ in between the LL and UL that confirms no mediation effect (Preacher and Hayes, 2008). Therefore, all the mentioned results presented in Table 7 and Fig. 3.

Table 7

Mediation (indirect effect) result

\begin{tabular}{|llllllll|}
\hline Hypotheses & $\begin{array}{l}\text { OS } \\
\text { (Beta) }\end{array}$ & LB & UB & T & P & Decision & Mediation \\
\hline $\begin{array}{l}\text { H5: GRC -> EMP -> Green } \\
\text { HRM }\end{array}$ & 0.081 & 0.012 & 0.168 & 1.975 & 0.049 & Significant & Partial \\
\hline $\begin{array}{l}\text { H6: GSC -> EMP -> Green } \\
\text { HRM }\end{array}$ & 0.017 & -0.057 & 0.086 & 0.469 & 0.639 & $\begin{array}{l}\text { Not } \\
\text { Significant }\end{array}$ & No Mediation \\
\hline $\begin{array}{l}\text { H7: GHC -> EMP } \rightarrow \text { Green } \\
\text { HRM }\end{array}$ & 0.048 & 0.014 & 0.100 & 2.102 & 0.036 & Significant & Partial \\
\hline
\end{tabular}




\section{Discussion}

Data analysis of the study predicts that environment management practice has a significant influence in the relationship between green human capital and green human resource management, and green relational capital and green human resource management. Surprisingly, environment management practice does not play any significant mediating role in between green structural capital and green human resource management. In addition, green human capital and green relational capital has a significant direct influence on green human resource management. However, green structural capital does not have any significant direct impact on green human resource management. These findings indicate that, developing countries need to adopt environmental management practices for getting the synergetic move in getting the green relational capital and green human capital. The Asian countries like Pakistan and Bangladesh are facing severe shortage of the as compared to the developed countries like ...therefore, we have to do a lot for creating awareness regarding environmental protection, reservation and posturing. Due to severe dust and pollution problems in the universe, depletion of ozone layer, human us needed to adopt green environmental practices, should come to their natural practices. Therefore, the natural and biological scientists are pushing towards 'back to basic' theories and practices.

\section{Limitations of the study}

Firstly, the study only measured the existing state of the RMG industry for which this research does not allow to examine either the short or long-term effects of green IC on green HRM. In future, a longitudinal study can be carried out observe the practices of green HRM and examines how the relationship between variables changes over time. Secondly, the study was conducted under positivism paradigm and quantitative methodology for which self-reported survey was conducted and the data was collected from the representatives of RMG industry. Since one person was chosen for representing their company that's why a potential common method variance problem was inevitable. Therefore, future study can be conducted by representing more than one from each firm and a mixed method study can be conducted. Lastly, the study was conducted in a particular context (RMG industry in Dhaka region) which does not cover all RMG industry in Bangladesh and all kinds of industry. Therefore, the findings may not applicable to other economic, cultural, and industry set up.

\section{Suggestions for future research}

The further study can be conducted based on the limitations discussed in earlier section. Firstly, we recommend testing the model in other developing and developed countries' organizational and governance settings. Similarly, Artificial Intelligence (Al) is an emerging field and being utilized for environmental protection and upgradation, can be test as a mediator to assess its impact on green HRM practices and environment as a whole. Not only can that comparative research be conducted across various countries and cultural contexts that will provide a broader view and will enrich HRM literature. Lastly, the proposed model can be extended to include green CSR responsibility, competitive advantage, sustainability, and performance in future research. 


\section{Conclusion}

The massive care given to environmental concerns has fortified corporations to adopt green practices in their business, and GHRM is a necessary change, specifically in RMG industry, to build a green organizational identity. It is significant for producers to understand the driving force of the adoption of GHRM, to be aware of the benefits associated with GHRM, and to recognize the role of GHRM in supporting and perhaps even achieving business sustainability. This research assists as a first step in developing an ironic and evocative model of GHRM that is so essential for any profound understanding in future. Despite having numerous limitations, it is expecting that the researchers can use the results of this research as a future reference for the GHRM context.

\section{Declarations}

\section{Ethical Approval}

The study was independently designed and approved by Universiti Tenaga National (UNITEN) and Bahria University scholars and professors.

\section{Consent to Participate}

Informed consent was obtained from all individual participants included in the study.

\section{Consent to publish}

We, all the undersigned, give our consent for the publication of identifiable details, given in the manuscript.

\section{Authors Contributions}

The idea was conceived by Dr. Mohammad Nurul Alam and wrote the introduction and gap analysis. Dr. Jamshid Ali Turi revised the introduction and gap analysis and developed the rest of the literature and theoretical support for the paper with the active consultation of the Dr. Mohammad Nurul Alam and Sudhaishna Khastoori. Dr. Mohammad Nurul Alam and Sudhaishna Khastoori also helped in developing questionnaire. Data was collected by Rosima Bte. Alias, Md. Adnan Rahman and Md Suliman Hossin. The data was screened by all group members for anomalies and later the target test were applied for the needed analysis to get the objectives of the study. Moreover, in the last phase paper for all formalities were revised by every group member individually.

\section{Funding}

No funding available for this study.

\section{Competing Interests}


No competing interest

\section{Availability of data and materials}

All the data is merged in the text. No other data is available.

\section{References}

Abhayawansa, S., Guthrie, J., \& Bernardi, C. (2019). Intellectual capital accounting in the age of integrated reporting: a commentary. Journal of Intellectual Capital, Vol. 20 No. 1, , 1-9.

Agyabeng-Mensah, Y., Ahenkorah, E., Afum, E., Agyemang, A. N., Agnikpe, C., \& Rogers, F. (2020). Examining the influence of internal green supply chain practices, green human resource management and supply chain environmental cooperation on firm performance. Supply Chain Management, Vol. 25 No. 5, pp. 585-599. https://doi.org/10.1108/SCM-11-2019-0405, 585-600.

Akhtar, C. S., Ismail, K., Ndaliman, M. A., Hussain, J., \& Haider, M. (2015). Can Intellectual Capital of SMEs Help in Their Sustainability Efforts. Journal of Management Research, Vol. 7, No. 2, 82-98.

Alam, M. N., Hassan, M. M., Bowyer, D., \& Reaz, M. (2020). The Effects of Wages and Welfare Facilities on Employee Productivity: Mediating Role of Employee Work Motivation. Australasian Accounting, Business and Finance Journal, 14(4), 38-60.

Alam, M. N., \& Alias, R. (2018). The mediating role of employee work motivation in the relationship between social compliance and employee productivity: A conceptual framework. International Journal of Development and Sustainability, 7(10), 2528-2540.

Alam, M. N., Alias, R. B., \& Azim, M. T. (2018). Social Compliance Factors (SCF) Affecting Employee Productivity (EP): An Empirical Study on RMG Industry in Bangladesh. Pacific Business Review International, 10(8), 87-96.

Alam, M. N., Azim, M. T., \& Alias, R. B. (2017). Social Compliance in Ready-Made Garment Industry in Bangladesh: Challenges for HR Personnel. Journal of Applied Environmental and Biological Sciences, 7(10), 8-18.

Alfaro-Navarro, J.-L., López-Ruiz, V.-R., \& Peña, D. N. (2017). A New Sustainability City Index Based on Intellectual Capital Approach. Sustainability 2017, 9(5), 860; https://doi.org/10.3390/su9050860, 1-13.

Anwar, N., Mahmood, N. H., Yusliza, M. Y., Ramayah, T., Faezah, J. N., \& Khalid, W. (2020). Green Human Resource Management for organisational citizenship behaviour towards the environment and environmental performance on a university campus. Journal of Cleaner Production Volume 256, 20, 1-13.

B.Hodson, C., \& A.Sander, H. (2017). Green urban landscapes and school-level academic performance. Landscape and Urban Planning Volume 160, 16-27. 
Bongartza, D., Doré, L., Eichler, K., Grubed, T., Heuser, B., Hombach, L. E., .. . Mitsos, A. (2018). Comparison of light-duty transportation fuels produced from renewable hydrogen and green carbon dioxide. Applied Energy Volume 231, 757-767.

Cavicchi, C., \& Vagnoni, E. (2017). Does intellectual capital promote the shift of healthcare organizations towards sustainable development? Evidence from Italy. Journal of Cleaner Production Volume 153, 1 , https://doi.org/10.1016/j.jclepro.2017.03.175, 275-286.

Chiappini, R., \& Lahet, D. (2020). Exchange rate movements in emerging economies - Global vs regional factors in Asia. China Economic Review Volume 60, https://doi.org/10.1016/j.chieco.2019.101386, 50-67.

Colding, J., Wallhagen, M., Sörqvist, P., Marcus, L., Hillman, K., Samuelsson, K., \& Barthel, S. (2020). Applying a Systems Perspective on the Notion of the Smart City. Smart Cities, Volume 3, Issue 2, https://doi.org/10.3390/smartcities3020022, 420-429.

Cruz-González, J., López-Sáez, P., Navas-López, J. E., \& Delgado-Verde, M. (2015). Open search strategies and firm performance: The different moderating role of technological environmental dynamism. Technovation Volume 35, , 32-45.

Curado, C., \& Bontis, N. (2006). The knowledge-based view of the firm and its theoretical precursor. International Journal of Learning and Intellectual Capital, Volume 3, Issue 4 .https://doi.org/10.1504/IJLIC.2006.011747, 367-383.

Delgado-Verde, M., Amores-Salvadó, J., Castro, G. M.-d., \& Navas-López, J. E. (2014). Green intellectual capital and environmental product innovation: the mediating role of green social capital. Knowledge Management Research \& Practice volume 12, https://doi.org/10.1057/kmrp.2014.1, 261-275.

Derkzen, M. L., Teeffelen, A. J., \& Verburg, P. H. (2017). Green infrastructure for urban climate adaptation: How do residents' views on climate impacts and green infrastructure shape adaptation preferences? Landscape and Urban Planning Volume 157, 106-130.

Fukuda, S.-i., \& Tanaka, M. (2020). Financial Spillovers in Asian Emerging Economies. Asian Development Review Volume 37, Issue, 93-118.

Islam, M. A., Jantan, A. H., Aldaihani, F. M. F., Rahman, M. A., Khan, A. M., Shahin, S., \& Alam, M. N. (2018). Impact of Empowerment, Flexibility and Trust on Women's Access to Senior Positions in Rmg Industry of Bangladesh. International Journal of Entrepreneurship, 22(3), 1-11.

Hassan, M. M., Jambulingam, M., Alam, M. N., \& Islam, M. S. (2019). Redesigning the Retention Strategy against the Emerging Turnover of Generation Y: Revisiting the Long-standing Problems from 20th to 21st century. International Journal of Entrepreneurship, 23(2).

Heiman, B., \& Nickerson, J. A. (2010). Towards Reconciling Transaction Cost Economics and the Knowledge-based View of the Firm: The Context of Interfirm Collaborations. International Journal of the 
Economics of Business Volume 9, 2002 - Issue 1.https://doi.org/10.1080/13571510110103001, 97-116.

Hickel, J., \& Kallis, G. (2020). Original Articles Is Green Growth Possible? New Political Economy Volume 25, 2020 - Issue 4, 469-486.

Hörisch, J., Johnson, M. P., \& Schaltegger, S. (2015). Implementation of Sustainability Management and Company Size: A Knowledge-Based View. Business Strategy and The Environment, Volume24, Issue8, https://doi.org/10.1002/bse.1844, 765-779.

Jennings, V., \& Bamkole, O. (2019). The Relationship between Social Cohesion and Urban Green Space: An Avenue for Health Promotion. International Journal of Environmental Research and Public Health, Volume 16 Issue 3 10.3390/ijerph16030452, 56-78.

Kianto, A., Sáenz, J., \& Aramburu, N. (2017). Knowledge-based human resource management practices, intellectual capital and innovation. Journal of Business Research Volume 81, 11-20.

Alam, M. N., Alias, R. B., \& Hassan, M. M. (2019). Impact of Social Compliance on Employee Motivation: An Empirical Study. International Journal of Advanced Science and Technology. Vol. 28, No. 11, (2019), pp. 42-50.

Mansoor, A., Jahan, S., \& Riaz, M. (2021). Does green intellectual capital spur corporate environmental performance through green workforce? Journal of Intellectual Capital, https://doi.org/10.1108/JIC-062020-0181, 32-47.

Martin, S. L., \& Javalgib, R. G. (2019). Explaining performance determinants: A knowledge based view of international new ventures. Journal of Business Research Volume 101, 615-626.

Mas, F. D. (2019). The Relationship Between Intellectual Capital and Sustainability: An Analysis of Practitioner's Thought. Intellectual Capital Management as a Driver of Sustainability, https://doi.org/10.1007/978-3-319-79051-0_2, 290-311.

Massaro, M., Dumay, J., Garlatti, A., \& Mas, F. D. (2018). Practitioners' views on intellectual capital and sustainability: From a performance-based to a worth-based perspective. Journal of Intellectual Capital, Vol. 19 No. 2, https://doi.org/10.1108/JIC-02-2017-0033, 367-386.

Meijerink, J., \& Bondarouk, T. (2018). Uncovering configurations of HRM service provider intellectual capital and worker human capital for creating high HRM service value using fsQCA. Journal of Business Research Volume 82, 31-45.

Mousa, S. K., \& Othman, M. (2020). The impact of green human resource management practices on sustainable performance in healthcare organisations: A conceptual framework. Journal of Cleaner Production Volume 243, 78-101. 
Nikolaou, I. E. (2019). A Framework to Explicate the Relationship Between CSER and Financial Performance: an Intellectual Capital-Based Approach and Knowledge-Based View of Firm. Journal of the Knowledge Economy volume 10, https://doi.org/10.1007/s13132-017-0491-z, 1427-1446.

Paço, A. d., Shiel, C., \& Alves, H. (2019). A new model for testing green consumer behaviour. Journal of Cleaner Production Volume 207, 998-1006.

Petty, R., \& Guthrie, J. (2020). Intellectual capital literature review : Measurement, reporting and management. Journal of Intellectual Capital, Vol. 1 No. 2. https://doi.org/10.1108/14691930010348731, 155-176.

Pham, N. T., Thanh, T. V., Tučková, Z., \& NgocThuy, V. T. (2020). The role of green human resource management in driving hotel's environmental performance: Interaction and mediation analysis. International Journal of Hospitality Management Volume 88, 1-10.

Pham, N. T., Tučková, Z., \& Jabbour, C. J. (2019). Greening the hospitality industry: How do green human resource management practices influence organizational citizenship behavior in hotels? A mixedmethods study. Tourism Management Volume 72, 386-399.

Reed, K. K., Lubatkin, M., \& Srinivasan, N. (2006). Proposing and Testing an Intellectual Capital-Based View of the Firm. Journal of Managemet Studies, Volume 43, Issue 4, 867-893.

Rehman, S. U., Kraus, S., Shah, S. A., Khanin, D., \& Mahto, R. V. (2017). Analyzing the relationship between green innovation and environmental performance in large manufacturing firms. Technological Forecasting and Social Change, vol 63. https://doi.org/10.1016/j.techfore.2020.120481, 23-46.

RenataDagiliūtè, Liobikienè, G., \& Minelgaitè, A. (2018). Sustainability at universities: Students' perceptions from Green and Non-Green universities. Journal of Cleaner Production Volume 181, 473-482.

Saeed, B. B., Afsar, B., Hafeez, S., Khan, I., Tahir, M., \& Afridi, M. A. (2018). Promoting employee's proenvironmental behavior through green human resource management practices. Corporate Social Responsibility and Environmental Managementvolume26, Issue2, https://doi.org/10.1002/csr.1694, 424438.

Shukla, R. (2020). Impact of Information Technology on Human Resource Management. International Journal of Research in Business Studies, Vol. 5 (2), 81-91.

Singh, S. K., DelGiudice, M., Chierici, R., \& Graziano, D. (2020). Green innovation and environmental performance: The role of green transformational leadership and green human resource management. Technological Forecasting and Social Change Volume 150, 1-12.

Sokolov, D., \& Zavyalova, E. (2020). Human resource management systems and intellectual capital: is the relationship universal in knowledge-intensive firms? International Journal of Manpower, https://doi.org/10.1108/IJM-11-2018-0372, 23-47. 
Sousa, C. A., \& Hendriks, P. H. (2006). The Diving Bell and the Butterfly: The Need for Grounded Theory in Developing a Knowledge-Based View of Organizations. organizational research methods, Vol 9, Issue 3. https://doi.org/10.1177/1094428106287399, 315-338.

Su, L., \& R.Swanson, S. (2019). Perceived corporate social responsibility's impact on the well-being and supportive green behaviors of hotel employees: The mediating role of the employee-corporate relationship. Tourism Management Volume 72, 437-450.

Tang, G., Chen, Y., Jiang, Y., Paillé, P., \& Jia, J. (2018). Green human resource management practices: scale development and validity. Asia Pacific Journal of Human Resources, volume56, Issue1 , 31-55.

Villiers, C., \& Sharmac, U. (2020). A critical reflection on the future of financial, intellectual capital, sustainability and integrated reporting. Critical Perspectives on Accounting Volume 70, 1-13.

Wu, G.-C. (2013). The influence of green supply chain integration and environmental uncertainty on green innovation in Taiwan's IT industry. Supply Chain Management, Vol. 18 No. 5. https://doi.org/10.1108/SCM-06-2012-0201, 539-552.

Xu, J., \& Wang, B. (2018). Intellectual Capital, Financial Performance and Companies' Sustainable Growth: Evidence from the Korean Manufacturing Industry. Sustainability 2018, 10(12), 4651; https://doi.org/10.3390/su10124651, 1-22.

Yong, J. Y., Yusliza, M.-Y., Ramayah, T., \& Fawehinmi, O. (2019). Nexus between green intellectual capital and green human resource management. Journal of Cleaner Production Volume 215, 1, https://doi.org/10.1016/j.jclepro.2018.12.306, 364-374.

Yong, J. Y., Yusliza, M.-Y., Ramayah, T., Jose, C., Jabbour, C., Sehnem, S., \& Mani, V. (2020). Pathways towards sustainability in manufacturing organizations: Empirical evidence on the role of green human resource management. business strategy and the environment, Volume29, Issue1, https://doi.org/10.1002/bse.2359, 212-228.

Yu, W., Chavez, R., Feng, M., Wong, C. Y., \& Fynes, B. (2020). Green human resource management and environmental cooperation: An ability-motivation-opportunity and contingency perspective. International Journal of Production Economics Volume 219, 224-235.

Yuslizaa, M.-Y., YiYong, J., Tanveer, M. I., Ramayah, T., Faezah, J. N., \& Muhammad, Z. (2020). A structural model of the impact of green intellectual capital on sustainable performance. Journal of Cleaner Production Volume 249, https://doi.org/10.1016/j.jclepro.2019.119334, 291-311.

Yusoff, Y. M., Nejati, M., Kee, D. M., \& Amran, A. (2020). Linking Green Human Resource Management Practices to Environmental Performance in Hotel Industry. Global Business Review Vol 21, Issue 3, https://doi.org/10.1177/0972150918779294, 663-680. 
Yusoff, Y. M., Omar, M. K., Delim, M., Zaman, K., \& Samad, S. (2019). Do all elements of green intellectual capital contribute toward business sustainability? Evidence from the Malaysian context using the Partial Least Squares method. Journal of Cleaner Production Volume 234,

https://doi.org/10.1016/j.jclepro.2019.06.153, 626-637.

\section{Figures}

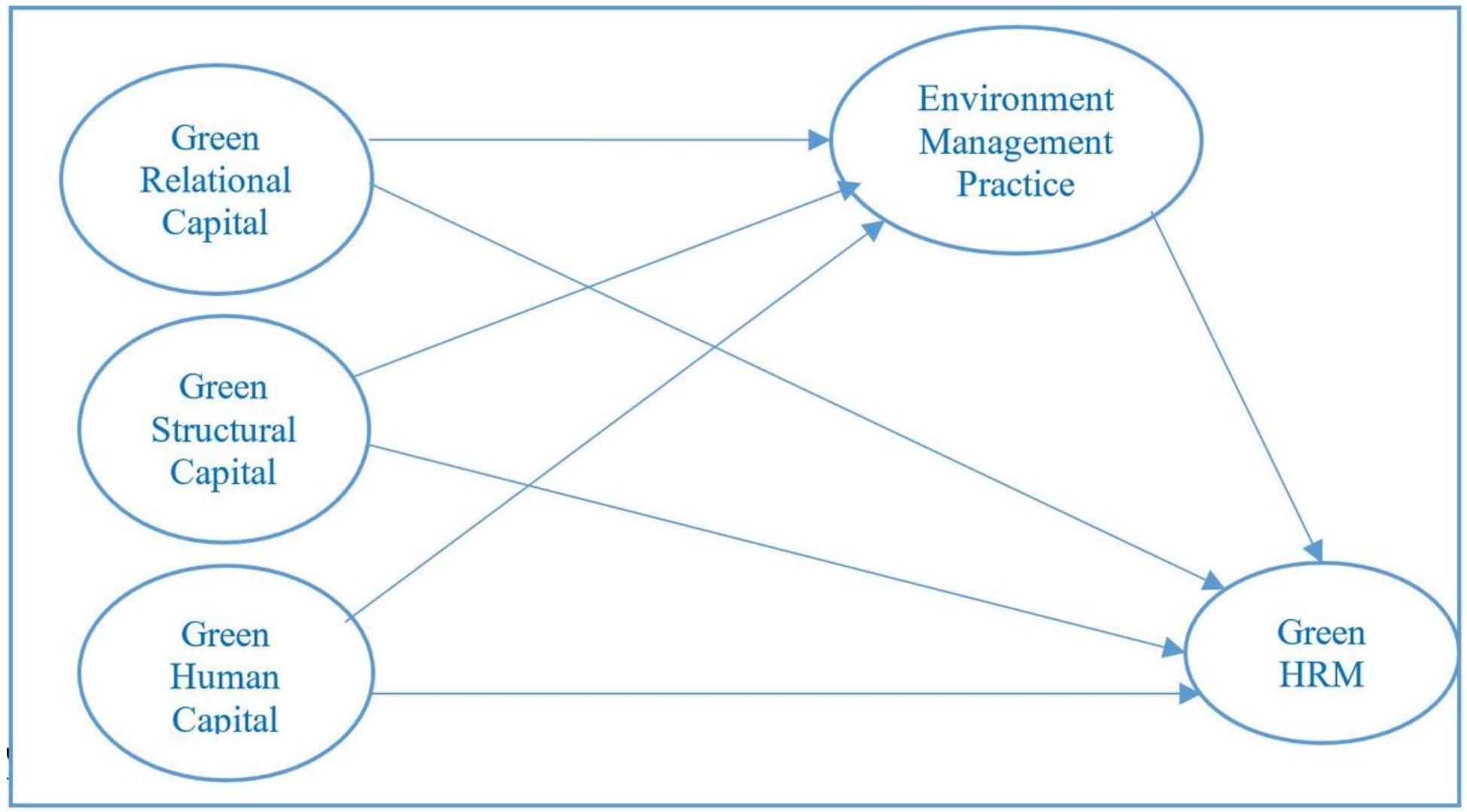

Figure 1

Conceptual Framework. 


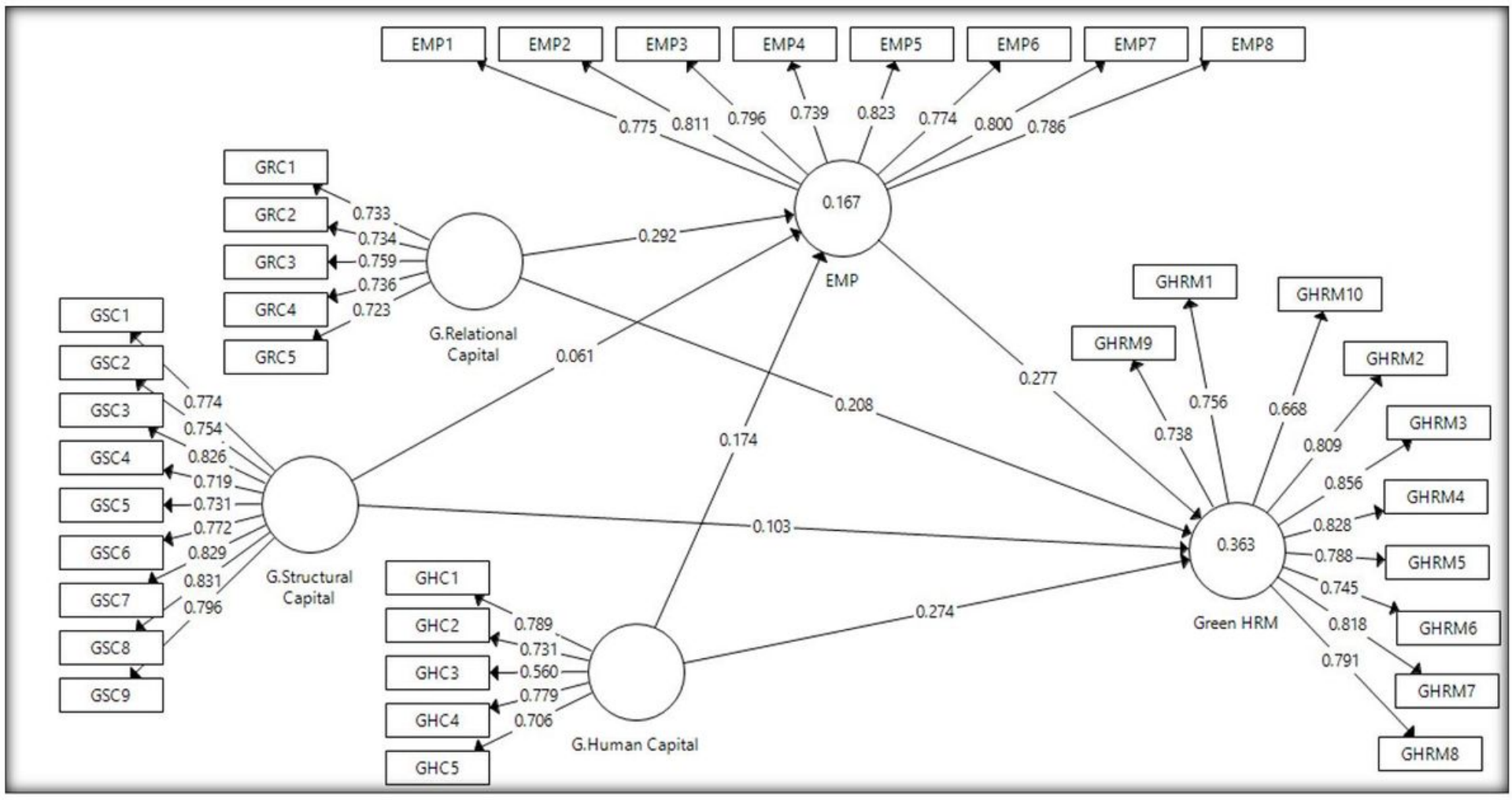

Figure 2

Factor loadings, path coefficient and R-square result (PLS-Algorithm)

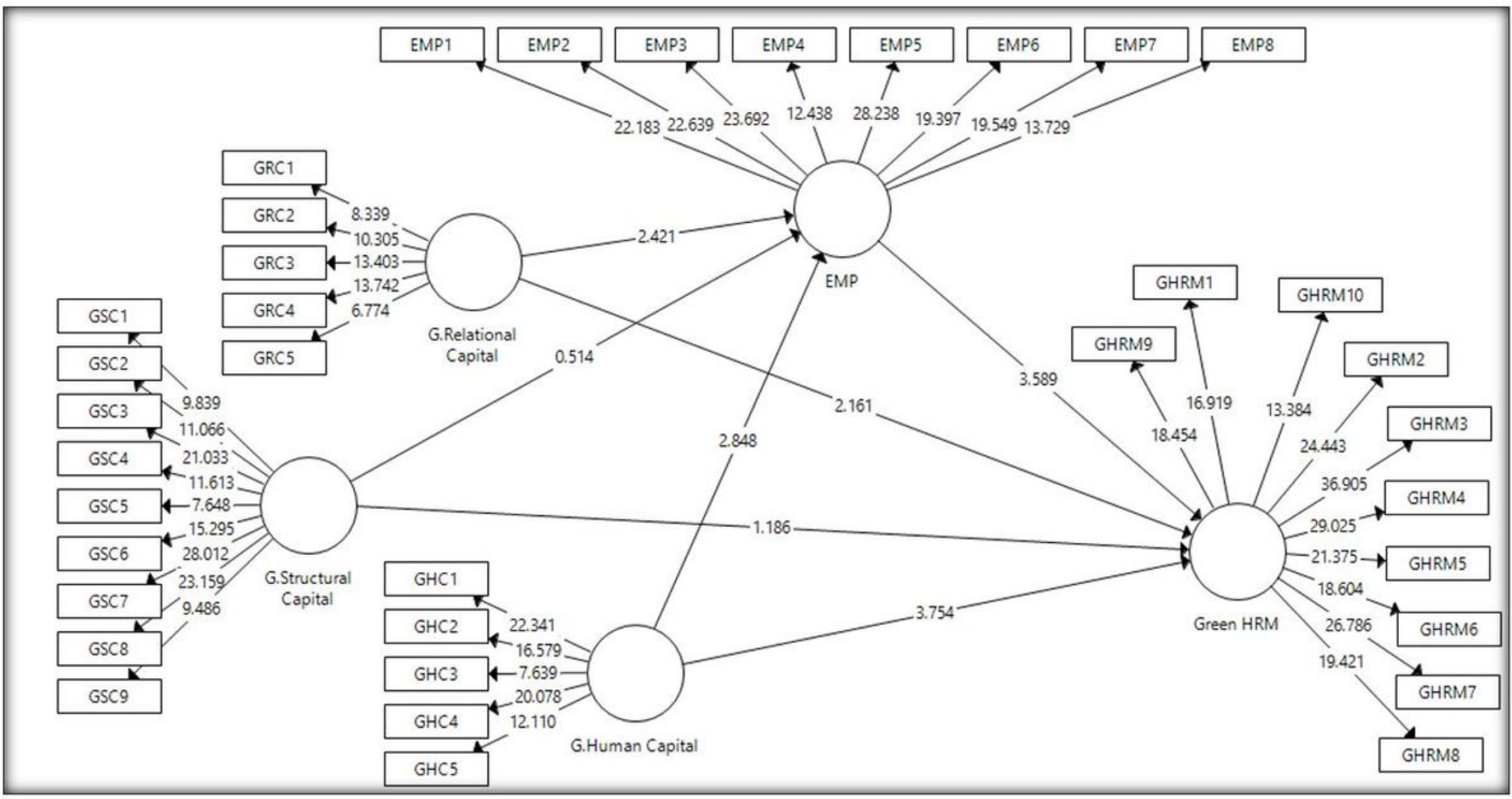

Figure 3

Bootstrapping results with inner model t-values. 